\title{
Aechmea e gêneros relacionados (Bromelioideae, Bromeliaceae) no Parque Nacional da Serra dos Órgãos, Rio de Janeiro, Brasil
}

Aechmea and allied genera (Bromelioideae, Bromeliaceae) from Serra dos Órgãos National Park, Rio de Janeiro, Brazil

\author{
Beatriz Neves ${ }^{1}$, Fernando Pérez Uribbe ${ }^{1}$, Suara Souza Almeida Jacques ${ }^{1}$, Bruno Paixão-Souza ${ }^{1}$, Ricardo \\ Loyola de Moura ${ }^{2}$, Ana Angélica Monteiro de Barros ${ }^{3} \&$ Andrea Ferreira da Costa ${ }^{2,4}$
}

\begin{abstract}
Resumo
O Parque Nacional da Serra dos Órgãos (PARNASO) constitui um dos maiores remanescentes de Mata Atlântica no estado do Rio de Janeiro. Bromeliaceae possui neste bioma um dos seus principais centros de diversidade, com 31 gêneros e 803 espécies, sendo mais de 500 pertencentes à subfamília Bromelioideae. Como parte do projeto Bromeliaceae organensis desenvolvido no Departamento de Botânica do Museu Nacional- UFRJ, o presente trabalho buscou inventariar as espécies de Aechmea, Billbergia, Hohenbergia e Quesnelia no PARNASO, fornecendo a descrição morfológica das espécies e uma chave para identificação, além de dados sobre sua distribuição, geral e dentro do parque. O estudo taxonômico foi realizado através da análise de material herborizado, coletas e observações de campo. Foram encontradas no parque: seis espécies de Aechmea, cinco de Billbergia, uma de Hohenbergia e quatro de Quesnelia. Apesar de bem representado em número de espécies na unidade de conservação, Billbergia conta com poucos registros nos herbários, sendo quatro de suas espécies referenciadas por um ou poucos indivíduos nas coleções. A localidade guarda ainda populações de espécies endêmicas do estado do Rio de Janeiro, como A. wellbachii, A. fasciata, $Q$. lateralis e Q. edmundoi var. edmundoi.
\end{abstract}

Palavras-chave: Aechmea, Billbergia, Floresta atlântica brasileira, Hohenbergia, Quesnelia.

\begin{abstract}
The Serra dos Órgãos National Park (PARNASO) constitutes one of the largest remnants of the Brazilian rainforest in Rio de Janeiro state. In this biome, Bromeliaceae has one of its main centers of diversity, with 31 genera and 803 species, being more than 500 belonging to the subfamily Bromelioideae. As a part of the project Bromeliaceae organensis in development in the Departament of Botany of the Museu NacionalUFRJ, the present work aims to inventory the species of Aechmea, Billbergia, Hohenbergia and Quesnelia on PARNASO, providing the morphological description of the species and an identification key, in addition to data about its distribution, general and inside the park. The taxonomic study was carried on through the analysis of the dried specimens, collections and field observations. Six species of Aechmea, five of Billbergia, one of Hohenbergia and four of Quesnelia, were revealed. Although well represented in number of species, Billbergia counts with a poor number of herbarium records, with four of them referenced by one or little more individuals in the collections. The locality also houses populations of endemic species of Rio de Janeiro state, like A. wellbachii, A. fasciata, Q. lateralis and Q. edmundoi var. edmundoi.
\end{abstract}

Key words: Aechmea, Billbergia, Brazilian atlantic rainforest, Hohenbergia, Quesnelia.

\footnotetext{
${ }^{1}$ Universidade Federal do Rio de Janeiro, Museu Nacional, PPGBOT, Quinta da Boa Vista, São Cristóvão, 20940-040, Rio de Janeiro, RJ, Brasil

${ }^{2}$ Universidade Federal do Rio de Janeiro, Museu Nacional, Depto. Botânica, Quinta da Boa Vista, São Cristóvão, 20940-040, Rio de Janeiro, RJ, Brasil

${ }^{3}$ Universidade do Estado do Rio de Janeiro, Faculdade de Formação de Professores, Depto. Ciências, Patronato, 24435-005, São Gonçalo, RJ, Brasil

${ }^{4}$ Autor para correspondência: afcosta@acd.ufrj.br
} 


\section{Introdução}

A Mata Atlântica é mundialmente conhecida por sua alta diversidade biológica e pelo alto grau de endemismo. No entanto, devido à intensa devastação e ameaça é considerada um dos 34 hotspots de biodiversidade do planeta (Myers et al. 2000).

A Serra dos Órgãos constitui um dos maiores remanescentes contínuos deste bioma no estado do Rio de Janeiro, sendo indicada pelo Ministério do Meio Ambiente como de extrema relevância para a conservação da biodiversidade (ICMBIO 2014). Localizado entre os municípios fluminenses de Guapimirim, Magé, Petrópolis e Teresópolis, o Parque Nacional da Serra dos Órgãos (PARNASO) guarda em seus domínios o trecho mais escarpado de toda a Serra do Mar. Por sua vegetação exuberante e rica, a região atraiu a atenção de grandes naturalistas, entre eles Auguste Glaziou e Alexandre Curt Brade. Em trabalho intitulado Flora organensis, Rizzini (1954) deixou sua contribuição identificando 2.003 espécies vegetais na unidade de conservação.

A família Bromeliaceae é considerada uma das principais famílias botânicas do neotrópico, compreendendo 3.352 espécies e 58 gêneros (Luther 2012). Atualmente, são reconhecidas oito subfamílias: Bromelioideae, Tillandsioideae, Pitcairnioideae, Brocchinioideae, Lindmanioideae, Hechtioideae, Navioideae e Puyoideae (Givnish et al. 2007, 2011). No Brasil, são registrados 43 gêneros e 1.246 spp., das quais 1.067 (cerca de $32 \%$ ) são endêmicas do país (Forzza et al. 2014).

Bromeliaceae possui na Mata Atlântica um dos seus principais centros de diversidade, com 31 gêneros e 803 spp. com destaque a subfamília Bromelioideae, com mais de $500 \mathrm{spp}$. ocorrendo no domínio da Mata Atlântica (Martinelli et al. 2008).

A imprecisão nos limites genéricos na subfamília Bromelioideae é evidente, sobretudo nos gêneros relacionados à Aechmea, como Billbergia, Hohenbergia e Quesnelia (Faria et al. 2004; Almeida et al. 2009; Sass \& Specht 2010).

O presente trabalho faz parte do projeto Bromeliaceae organensis desenvolvido no Departamento de Botânica do Museu NacionalUFRJ, e teve como objetivos: inventariar as espécies de Aechmea, Billbergia, Hohenbergia e Quesnelia no PARNASO, fornecer a descrição morfológica e uma chave de identificação dos táxons, além de dados sobre sua distribuição, geral e dentro do parque.

\section{Material e Métodos}

Área de Estudo

O Parque Nacional da Serra dos Órgãos abrange uma área que totaliza 20.024 hectares, localizado nos municípios de Teresópolis, Petrópolis, Magé e Guapimirim, no estado do Rio de Janeiro (ICMBIO 2014) (Fig. 1a).

Diferentes formações vegetais são encontradas no PARNASO de acordo com a altitude. No entorno do Parque, entre $300-800 \mathrm{~m}$, predomina a Floresta Pluvial Baixo-Montana. Entre cerca de 800 e 1.500-1.700m de altitude ocorre a floresta montana, que ocupa a maior área do Parque. A floresta altomontana, típica mata úmida de neblina localizada nas partes mais altas, ocorre entre $1.500-1.800 \mathrm{~m}$ de altitude. A partir de 1.800 metros, predomina uma vegetação mais baixa e aberta, dominada por vegetação herbáceo-arbustiva se desenvolvendo sobre afloramentos rochosos, os planaltos serranos (Rizzini 1979), que caracterizam os campos de altitude.

O Parque apresenta grande parcela de floresta primária ou em estágio avançado de sucessão que somada às áreas preservadas do campo de altitude, vegetação rupestre e afloramentos rochosos totalizam 81,2\% (Cronemberger \& Viveiros-De-Castro 2007).

\section{Estudo Taxonômico}

O estudo taxonômico foi realizado através da análise de material herborizado, coletas, observações de campo e consulta às coleções de espécimes cultivados. Foram consultados os herbários R, RB, GUA, RFFP e HB para análise taxonômica e medição das estruturas morfológicas, além das imagens de exsicatas depositadas nos herbários $\mathrm{GH}$, US, F, Z e S citadas por Smith \& Downs (1979) para a região.

A identificação do material foi realizada com o auxílio de chaves, comparação com outros materiais e consulta à literatura especializada. As descrições realizadas seguindo a terminologia usual para a família (Smith \& Downs 1979), modificada com Radford (1986) para descrição das formas e posturas, e Scharf \& Gouda (2008), para o uso do termo pedúnculo designando o eixo que sustenta a parte fértil da inflorescência. Os materiais examinados foram organizados por ordem alfabética do município onde foi realizada a coleta, seguido pela ordem cronológica de coleta e número de coletor. Dados referentes à distribuição geográfica foram baseados das etiquetas dos materiais dos herbários 
e da literatura (Martinelli et al. 2008; Forzza et al. 2014), além das observações de campo. Dados descritivos sobre o espécime registrados nas etiquetas também foram utilizados. O material coletado foi depositado no Herbário R.

\section{Resultados e Discussão}

Foram encontradas no PARNASO 16 espécies, sendo seis do gênero Aechmea, cinco de Billbergia, uma de Hohenbergia e quatro de Quesnelia.

\section{Chave para a identificação das espécies}

1. Pétalas recurvadas a revolutas. Ovário sulcado.

2. Pétalas revolutas; anteras basifixas; ovário turbinado. 11. Billbergia zebrina

2'. Pétalas recurvadas a fortemente recurvadas; anteras dorsifixas; ovário subcilíndrico ou cilíndrico.

3. Pedúnculo da inflorescência e raque lanuginosos ..... 9. Billbergia pyramidalis

3'. Pedúnculo da inflorescência e raque com indumento lepidoto esparso a glabros.

4. Lâmina foliar com dobra na base

8. Billbergia horrida

4'. Lâmina foliar sem dobra na base.

5. Pedúnculo da inflorescência ereto a subereto. Inflorescência sempre laxa. Sépala verde com ápice azul. Estigma verde ou azul ....

7. Billbergia amoena

5'. Pedúnculo da inflorescência pendente. Inflorescência laxa na base e congesta no ápice. Sépala com base rósea e ápice azul. Estigma roxo.

10. Billbergia sanderiana

1. Pétalas eretas. Ovário não sulcado.

6. Inflorescência composta com ramificações de terceira ordem

6'. Inflorescência simples ou composta com ramificações de segunda ordem.

12. Hohenbergia augusta

7. Sépalas assimétricas com ápice apiculado.

8. Inflorescência simples.

9. Inflorescência estrobiliforme; brácteas do pedúnculo fortemente imbricadas e com margem serrada; brácteas florais com margem serrada.

5. Aechmea pectinata

9'. Inflorescência espiciforme; brácteas do pedúnculo não imbricadas ou pouco imbricadas e com a margem inteira; brácteas florais com margem inteira.

10. Lâmina foliar com margem serrada; brácteas do pedúnculo maiores que $4 \mathrm{~cm}$; brácteas florais mais curtas que os ovários; pétalas amarelas

4. Aechmea nudicaulis

10'. Lâmina foliar com margem esparsamente serrilhada; brácteas do pedúnculo menores que $3 \mathrm{~cm}$; brácteas florais mais longas que os ovários; pétalas azuis

8'. Inflorescência composta.

3. Aechmea gracilis

11. Lâmina foliar com faixas alvas na face abaxial; pedúnculo róseo; brácteas do pedúnculo com margem serrada; brácteas florais maiores que $25 \mathrm{~mm}$ compr.

2. Aechmea fasciata

11'. Lâmina foliar completamente verde; pedúnculo não róseo; brácteas do pedúnculo com margem inteira; brácteas florais menores que $20 \mathrm{~mm}$ compr.

12. Pedúnculo pendente; sépalas conatas em menos de $2 / 3$ do seu comprimento; ovário arredondado. 6. Aechmea weilbachii

12'. Pedúnculo ereto a subereto; sépalas conatas em $2 / 3$ ou mais do seu comprimento; ovário cilíndrico.

13. Brácteas florais mais curtas ou igualando as sépalas; inflorescência com mais de $7 \mathrm{~cm}$ e com muitas ramificações na base

1. Aechmea coelestis

13'. Brácteas florais mais longas que as sépalas; inflorescência com menos de $6 \mathrm{~cm}$ e com pouquíssimas ramificações na base.

3. Aechmea gracilis 
7'. Sépalas levemente assimétricas e ápice obtuso.

14. Inflorescência laxa; brácteas florais mais curtas que as sépalas; sépalas curto-conatas .

15. Quesnelia liboniana

14'. Inflorescência congesta; brácteas florais mais longas que as sépalas; sépalas conatas ou livres.

15. Inflorescência fusiforme, lateral raramente terminal; brácteas do pedúnculo com margem inteira, vermelhas; pétalas com ápice subereto

14. Quesnelia lateralis

15'. Inflorescência estrobiliforme, terminal; brácteas inferiores do pedúnculo com margem serrilhada, medianas e superiores com margem inteira, esverdeadas ou estramíneas; pétalas cuculadas.

16. Lâmina foliar verde com bandas transversais alvacentas na face abaxial; brácteas inferiores do pedúnculo foliáceas e as superiores estramíneas; brácteas florais crispadas na margem e com indumento lanuginoso alvo; sépalas róseas e esparso-lanuginosas.....

16. Quesnelia quesneliana

16'. Lâmina foliar verde; brácteas do pedúnculo não foliáceas, esverdeadas; brácteas florais lisas e glabras; sépalas albo-amareladas e glabras

13. Quesnelia edmundoi var. edmundoi

\section{Aechmea}

É o mais diverso da subfamília, com cerca de 276 espécies (Luther 2012). A Mata Atlântica é o centro de diversidade para o grupo (Smith 1934), que apresenta $70 \%$ de seus táxons distribuídos no Brasil (Smith \& Downs 1979; Luther 2012). Está dividido em oito subgêneros (Smith \& Downs 1979): A. subg. Aechmea, A. subg. Chevaliera, $A$. subg. Lamprococcus, A. subg. Macrochordion, A. subg. Ortgiesia, A. subg. Platyaechmea, A. subg. Podaechmea e A. subg. Pothuava. No PARNASO, Aechmea é bem representado em número de registros. Em geral, suas espécies não formam grandes populações na localidade, exceto $A$. wellbachii, que apresenta densos aglomerados nas margens dos rios Bananal e Soberbo. A UC guarda populações de espécies endêmicas do estado do Rio de Janeiro, como A. wellbachii e A. fasciata, além das endêmicas do domínio atlântico: A. coelestis, A. gracilis e A. pectinata.

1. Aechmea coelestis (K. Koch) E. Morren, Fl. Serres 21: 5, pl. 2146. 1875. Fig. 1e

Planta epífita ou terrestre, com cerca de 50 $\mathrm{cm}$ alt. quando florida. Roseta formando tanque, infundibuliforme. Folhas suberetas; bainha 11-22,5 $\times 4,5-9 \mathrm{~cm}$, estreito-elíptica a elíptica, alva a levemente arroxeada, indumento lepidoto, castanho denso; lâmina estreito-oblonga a linear, 9-57 × 3,2-6,5 cm, margem serrada, ápice arredondado acuminado-pungente, verde com indumento lepidoto prateado pouco denso na face adaxial e denso na face abaxial. Inflorescência terminal, ereta, dupla espiga heterotética, piramidal, com muitas ramificações na base, 7-15,5 × 3-7,5 cm congesta; pedúnculo ereto a subereto, $18-54 \mathrm{~cm}$ de compr., $0,3-0,7 \mathrm{~cm}$ de diâmetro, verde com indumento lanuginoso alvo; brácteas do pedúnculo todas diferentes das folhas, eretas, geralmente mais curtas que os entrenós, as medianas 2,5-4,5 × 0,6-1,2 cm, estreito-elípticas, ápice atenuado e acuminado, margem inteira, róseas, verdes ou estramíneas, indumento lanuginoso alvo; ramos patentes, raque reta, brácteas estéreis presentes no ápice dos ramos, indumento lanuginoso alvo; brácteas primárias $1,7-3,0 \times 0,4-0,8 \mathrm{~cm}$, mais longas que o pedúnculo dos ramos, estreito-elípticas, ápice atenuado, acuminado ou acuminado-pungente, indumento lanuginoso alvo; brácteas florais $0,8-1,2$ $\times 0,3-0,5 \mathrm{~cm}$, mais curtas a igualando as sépalas, ovadas, ápice atenuado, pungente, margem inteira, róseas, indumento lanuginoso alvo, sem carena. Flores polísticas, suberetas, sésseis; sépalas ca. $7 \times$ $3 \mathrm{~mm}$, assimétricas, ápice assimétrico, apiculado, margem inteira, sem carena, conatas em mais de $2 / 3$ do seu comprimento, verdes ou vermelhas, indumento lanuginoso alvo; pétalas $1-1,2 \times 0,2-0,4$ $\mathrm{cm}$, azuis, eretas, apêndices lingulados fimbriados no ápice, ca. 0,5 × 0,1 cm; ovário ínfero, cilíndrico, não sulcado, tubo epigíneo ca. $8 \mathrm{~mm}$, placenta localizada em todo o lóculo. Fruto baga.

É endêmica do Domínio Atlântico, ocorrendo nos estados do Espírito Santo, Rio de Janeiro, São Paulo e Paraná, nas Florestas Pluvial Tropical, Mata de Araucária e em matas de Restinga. No PARNASO forma grandes populações epífitas no interior da mata no Setor da Trilha da Pedra do Sino, entre altitudes de 750 a 1560 m.s.m. Ocorre também nas matas do Setor Dedo de Deus. 
Aechmea coelestis pertence a A. subg. Ortigiesia, cujas espécies apresentam evidente semelhança morfológica e consequente dificuldade de delimitação entre elas. A espécie mais próxima é A. organensis Wawra, cuja diferenciação é difícil, e apesar de já ter sido discutida por diferentes autores (Smith \& Downs 1979; Reitz 1983; Faria et al. 2004; Martins et al. 2007; Goetze 2014) sua identidade permanece desconhecida. O tipo de A. organensis foi destruído, o material Wawra 317 que serviu de base para a ilustração fornecida em Wawra (1883) foi designada como lectótipo (Till 1994).

Com isso, no presente trabalho, foi adotado apenas o nome $A$. coelestis, sendo o mais antigo entre eles, pois a análise das obras originais não permitiu a diferenciação entre elas. As informações sobre a distribuição geográfica levou em consideração os materiais depositados nos herbários R e RB após análise de material, e não foi baseada na literatura (e.g. Flora de São Paulo, Martins et al. 2007; Goetze 2014), uma vez que foram adotados diferentes conceitos para as espécies pelos diferentes autores. Apesar do estudo genético realizado por Goetze (2014) ainda restam muitas dúvidas quanto aos limites dos táxons. Mais estudos morfológicos e genéticos de ampla amostragem são necessários para o melhor entendimento do grupo.

Material selecionado: Teresópolis, V.1879, fl., $A$. Glaziou 11680 (F); 22.VIII.1940, fr., M. \& R. Foster 997 (GH); caminho para a Pedra do Frade, II.1952, fl., J. Vidal II.416 (R); caminho para a Pedra do Sino, 21.X.1977, fl., G. Martinelli 3321 (RB); travesssia da Neblina, trilha da Cabeça do Peixe, Uribbe 19 (R); próximo ao abrigo 1, 24.V.1987, fr., T. Fontoura 146 (RB); Cascata dos Amores, 02.VI.2011, fr., A. Costa 940 (R); margens do Rio Beija-Flor, 17.V.1983, fr., G. Martinelli 9305 (RB); Pedra do Sino, 06.V.2009, fl., A. Costa 893 (R); travessia da Neblina; 14.II.2012, fl., L.F. Gonçalves 41 (R); trilha da Cabeça do Peixe 18.VI.2011, fr., F.P. Uribbe 14 (R); Trilha do Nariz do Frade, 18.VI.2011, fr., F.P.Uribbe 19 (R) trilha suspensa, 18.X.2010, fr., R. Moura 978 (R).

2. Aechmea fasciata (Lindl.) Baker, Jour. Bot. London 17: 231. 1879.

Fig. 1f

Planta epífita ou rupícola. Roseta formando tanque, infundibuliforme. Folhas suberetas; bainha 12-20 × 5-9 cm estreito-elíptica a elíptica, alva na face abaxial e vinácea na adaxial, indumento lepidoto denso castanho; lâmina 27-76 × 4-7,5 $\mathrm{cm}$, linear a lanceolada, margem serreada, ápice arredondado a atenuado acuminado-pungente a pungente, verde e por vezes com faixas alvas na face abaxial, indumento lepidoto prateado. Inflorescência terminal, ereta a subereta, dupla espiga heterotética, estrobiliforme, congesta, 4-8 $\times 5-9 \mathrm{~cm}$; pedúnculo róseo, ereto a subereto, $28-51 \times 0,3-0,5 \mathrm{~cm}$, indumento lanuginoso alvo; brácteas do pedúnculo não foliáceas, róseas, eretas a suberetas, mais longas que os entrenós, as medianas $4-5,5 \times 0,5-0,8 \mathrm{~cm}$, lineares a elípticas, ápice atenuado e acuminadopungente, margem serrada, indumento lanuginoso alvo; ramos suberetos, raque reta, brácteas estéreis no ápice dos ramos, róseos, indumento lanuginoso alvo; brácteas primárias róseas, 4,5-6 × 0,8-1,5 $\mathrm{cm}$, mais longas que os ramos, lanceoladas, ápice atenuado e acuminado-pungente, margem serrada, indumento lanuginoso alvo; brácteas florais róseas, $3,2-4 \times 1-1,8 \mathrm{~cm}$, mais longas que as sépalas, estreito-elípticas a elípticas, ápice atenuado e acuminado-pungente, margem serrada, não carenadas, indumento lanuginoso alvo. Flores polísticas, suberetas, não secundas, sésseis; sépalas $10-15 \times 3-8 \mathrm{~mm}$, estreito-elípticas, assimétricas, ápice assimétrico, emarginado e apiculado, margem inteira, não carenadas, conatas, róseas, indumento lanuginoso alvo; pétalas eretas, ovário ínfero, cilíndrico, liso. Fruto baga.

Endêmica da Floresta Pluvial Tropical do estado do Rio de Janeiro, pertence à $A$. subg. Platyaechmea. No PARNASO é frequente ocorrendo entre as altitudes de 450-1000 m.s.m. nos quatro municípios. Ocorrem indivíduos isolados e epífitos no interior da mata. É próxima de A. delbata E. Morren ex Baker diferindo pela presença de ramificações na inflorescência e flores azuladas (Moura et al. 2007).

Material selecionado: Guapimirim, Trilha do Miudinho, 22.II.2011, fr., B. Neves 4 (R); Trilha para Poço Verde, 08.IV.2009, fr., A. Costa et al. 858 (R); Vale do Rio Bananal, 23.VIII.2009, fr., A. Costa et al. 880 (R); Vale do Rio Soberbo, trilha ao lado da ponte sobre o rio entre o KM 97-98 da rodovia BR-116, 22.VIII.2009, fr., A. Costa 873 et al. (R). Magé, Distrito de Piabetá, trilha para Petrópolis, 14.I.2009, fl., M. Nadruz 2267 (RB); Parque Nacional da Serra dos Órgãos, Serra da Estrela, 04.IX.2012, fr., F.P. Uribbe et al. 62 (R); Santo Aleixo, Próximo a cachoeira do Monjolo, 19.X.2010, fr., R. Moura 985 (R); Vale do Rio Santo Aleixo, Andorinhas, trilha Coruja-Italianos, fr., A. Costa 902 (R). Petrópolis, estrada Velha de Petrópolis, 10.IV.1952, fl., L.B. Smith 6459 (R, US). Teresópolis, I.1897, fr., $E$. Ule 4137 (CORD, R); Serra dos Órgãos, Rio Paquequer, 26.VII.1940, fl., A.C. Brade 16484 (RB); trilha da Cabeça do Peixe 18.VI.2011, fr., F.P. Uribbe 17 et al.(R); Trilha da Primavera, 21.II.2011, fr., B. Neves 1 (R). s. loc., road between Alto da Serra and Meio da Serra, 22.XII.1928, fl., L.B. Smith 1548 (GH). 
3. Aechmea gracilis Lindm., Svensk. Akad. Handl. 24(8): 30, pl. 6, figs. 10-16. $1891 . \quad$ Fig. 1b

Planta florida 30-50 cm, epífita. Roseta formando tanque, infundibuliforme. Folhas suberetas; bainha 11-15 × 3,5 cm, estreitooblonga, alva, indumento lepidoto castanho denso; lâmina linear 36-42 × 2,5-3,2 cm, estreitoelíptica, margem esparsamente serrilhada, ápice atenuado e acuminado, verde, indumento lepidoto levemente prateado. Inflorescência terminal, subereta, espiga ou dupla espiga heterotética, apresentando pouquíssimas ramificações na base, piramidal, levemente congesta, 4,5-6 × 2,5-3,2 $\mathrm{cm}$; pedúnculo róseo, subereto, $34-45 \times 0,2-0,3$ $\mathrm{cm}$, indumento lanuginoso alvo; brácteas do pedúnculo não foliáceas, róseas, eretas, imbricadas, mais longas que os entrenós, as medianas 1,8-3× $0,3-0,5 \mathrm{~cm}$, estreito-oblongas, ápice atenuado e acuminado, margem inteira, indumento lanuginoso alvo; ramos suberetos a patentes, raque reta, brácteas estéreis no ápice dos ramos, verdes, indumento lanuginoso alvo; brácteas primárias róseas, $1,8-2,3 \times 0,3-0,5 \mathrm{~cm}$, mais longas que o pedúnculo dos ramos, estreito-oblongas, ápice atenuado e acuminado, margem inteira, indumento lanuginoso alvo; brácteas florais róseas, $0,8-1,3 \times$ $0,3-0,5 \mathrm{~cm}$, mais longas que as sépalas, ovadas, ápice atenuado e pungente, margem inteira, não carenadas, indumento lanuginoso alvo. Flores polísticas, suberetas, não secundas, sésseis; sépalas $0,5-1 \times 0,2-0,4 \mathrm{~cm}$, assimétricas, ápice emarginado e apiculado, eretas, margem inteira, não carenadas, conatas em mais de $2 / 3$ do seu comprimento, róseas, indumento lanuginoso; pétalas $0,8-1,2 \times 0,3-0,4$ $\mathrm{cm}$, obovadas, ápice emargimando, cuculadas, livres, azuis, eretas, glabras, apêndices espatulados a obovais ca. $3 \times 1 \mathrm{~mm}$, estames inclusos, $0,4-0,7$ $\mathrm{cm}$, filetes filiformes, adnatos, anteras dorsifixas; ovário ínfero, cilíndrico, liso, placenta localizada em todo o lóculo. Fruto baga.

Endêmica do Domínio Atlântico, ocorrendo nos estados do Rio de Janeiro, São Paulo e Paraná, na Floresta Pluvial Tropical, Mata de Araucária e Restinga. No PARNASO, é conhecida para um pequeno trecho no Setor da Trilha da Pedra do Sino, onde forma pequena população epífita no interior da mata.

Assim como A. coelestis, A. gracilis também pertence ao subgênero Ortigiesia. A análise do protólogo (Lindman 1891) indica que, em relação às demais espécies mencionadas, é uma planta de menor porte, com inflorescência pouco ramificada ou simples e a margem foliar é esparsamente serrilhada. Sua distribuição também foi inferida das coleções do R e RB, não sendo encontrada em Santa Catarina conforme indicado por Martinelli et al. (2008).

Material selecionado: Teresópolis, trilha da Agulha do Beija-Flor, 23.II.2011, fl., B. Neves 8 et al. (R); trilha para o Rancho Frio, 22.I.2010, fl., J. Gomes-da-Silva 63 et al. (R).

4. Aechmea nudicaulis (L.) Griseb., Fl. Brit. W. Indies: 593. 1864.

Fig. 1d

Planta florida 30-70 cm, epífita. Roseta formando tanque, infundibuliforme. Folhas suberetas, bainha $15,5-21,5 \times 4,5-6,5 \mathrm{~cm}$, estreito-oblonga, verde, indumento lepidoto castanho denso; lâmina 21-35 × 4,5-6 cm, linear, margem serrada, ápice arredondado a atenuado, acuminado-pungente, verde, indumento lepidoto prateado. Inflorescência terminal, subereta, espiga, fusiforme, congesta, 4,7-6 × 1,5-2 cm; pedúnculo avermelhado, subereto a pendente, $32-40 \times 0,2-0,3$ $\mathrm{cm}$, indumento lanuginoso alvo denso; brácteas do pedúnculo não foliáceas, róseas, pouco imbricadas, suberetas, mais longas que os entrenós, as medianas 5-6,5 × 1,5-1,8 cm, estreito-elípticas, ápice arredondado e acuminado-pungentes, margem inteira, indumento lanuginoso alvo; brácteas florais vermelhas, ca. $1 \times 3 \mathrm{~mm}$, mais curtas que os ovários, triangulares, ápice atenuado e pungente, margem inteira, não carenadas, indumento lanuginoso alvo. Flores polísticas, suberetas, não secundas, sésseis; sépalas $0,5-0,7 \times 0,4-0,7$ $\mathrm{cm}$, assimétricas, ápice assimétrico, atenuado e apiculado, eretas, margem inteira, não carenadas, conatas, amarelas, indumento lanuginoso alvo; pétalas ca. $1,1 \mathrm{~cm}$, estreito-ovadas, ápice obtuso, cuculadas, livres, amarelas, eretas, indumento lanuginoso, apêndices lingulados minutos; estames inclusos, ca. $0,8 \mathrm{~cm}$, filetes filiformes, adnatos, anteras dorsifixas; ovário ínfero, cilíndrico, liso, ca. $0,6 \mathrm{~cm}$. Fruto baga.

Espécie de ampla distribuição na América do Sul (Wendt 1997; Moura et al. 2007), incluída em A. subg. Pothuava. No Brasil ocorre nos estados da Paraíba, Pernambuco, além de todo o Sudeste e o Sul, nas Florestas Pluvial Tropical, Floresta Estacional Mesófila Semidecídua, Mata de Araucária, nas Restingas e afloramentos rochosos. Apesar de a espécie apresentar ampla distribuição geográfica, não está bem representada no parque. Este fato provavelmente se deve à sua ocorrência 
preferencial em áreas abertas e de menores altitudes (Wendt 1997), as quais não ocorrem no parque.

Devido à sua ampla distribuição geográfica e variação morfológica, são conhecidas para a espécie quatro variedades e uma extensa lista de sinônimos (Smith \& Downs 1979). No entanto, como é uma espécie facilmente reconhecível, e por outro lado suas variedades são de difícil distinção, optamos por adotar o táxon somente no nível de espécie seguindo o conceito de Wendt (1997).

Material selecionado: Guapimirim, between Soberbo and Guapy, 18.XII.1928, fl. L.B. Smith 1531 (GH); PARNASO, próximo ao Museu Martius, 21.X.1977, fl., G. Martinelli 3338 (RB); próximo da preguiça, 12.VI.1997, fr., R. Moura 59 (R). Petrópolis, estrada Velha de Petrópolis, 10.IV.1952, fl., L.B. Smith 6494 (R); Serra da Estrela, antiga estrada de ferro, 30.III.1977, fr., G. Martinelli 1585 (RB). Teresópolis, 6.III.1956, fl., A. Abendroth 2 (US); Barreira, Serra dos Órgãos, 09.XII.1948, fl., A.P. Duarte (RB 65290); PARNASO, Rio Paquequer, 05.VII.2011, fl., L.F. Gonçalves 10 (R); Soberbo, 11.XI.1968, fl., D. Sucre 4101 (RB); id., Trilha suspensa,18.X.2010, fr., R. Moura et al. 991 (R). Road between Alto da Serra and Meio da Serra, 22.XII.1928, fl., L.B. Smith 1544 (GH).

5. Aechmea pectinata Baker, Jour. Bot. London 17: 233. 1879.

Fig.1c

Planta florida 40-70 cm, epífita ou rupícola. Roseta formando tanque, infundibuliforme. Folhas suberetas; bainha 5-15 × 4,5-10 cm, estreitoelíptica a elíptica, verde clara a alva, indumento lepidoto dourado denso; lâmina 85-120 × 4,5-9 $\mathrm{cm}$, estreito-elíptica, margem serrada, ápice atenuado e acuminado-pungente, verde, indumento lepidoto prateado. Inflorescência terminal, ereta a subereta, espiga, estrobiliforme, congesta, 8,5-11 $\times 5-6 \mathrm{~cm}$; pedúnculo ereto, $27-51 \times 0,5-0,8 \mathrm{~cm}$; brácteas do pedúnculo não foliáceas,verdes, imbricadas, mais longas que os entrenós, as medianas 9-15 × 2-2,5 cm, estreito-elípticas, ápice atenuado e acuminado-pungente, margem serrada, indumento lanuginoso alvo; brácteas florais róseas, $2,3-3,5 \times 0,6-0,7 \mathrm{~cm}$, mais longas ou igualando as sépalas, estreito-elípticas a elípticas, ápice atenuado e acuminado pungente, margem serrada, não carenadas, indumento lanuginoso alvo. Flores polísticas, suberetas, não secundas, sésseis; sépalas $1,7-2,2 \times 0,6-0,9 \mathrm{~cm}$, estreito-ovadas, assimétricas, ápice assimétrico, atenuado e pungente, eretas, margem inteira, não carenadas, conatas, indumento lanuginoso alvo; pétalas $2 \times 0,6 \mathrm{~cm}$, estreito-ovadas, ápice agudo, cuculadas, livres, alvas com ápice amarelo, eretas, indumento lanuginoso, apêndices lingulados, $0,1 \mathrm{~cm}$, calosidades presentes; estames inclusos, ca. $1 \mathrm{~cm}$, filetes filiformes, adnatos, anteras dorsifixas; ovário ínfero, cilíndrico, liso, ca. 0,6× $0,4 \mathrm{~cm}$. Fruto baga, 3,2 $\times 1,1 \mathrm{~cm}$.

Endêmica do Domínio Atlântico nos estados do Rio de Janeiro, São Paulo, Paraná e Santa Catarina, na Floresta Pluvial Tropical e na Restinga, está incluída em $A$. subg. Pothuava. No PARNASO é rara, provavelmente por ter sua ocorrência mais expressiva em cotas inferiores às do parque. Tem sua distribuição geográfica limitada à altitude de 1.100 m.s.m., fator que provavelmente influencia o baixo número de coletas na região. Foram observados indivíduos isolados, não formando grandes populações.

Material selecionado: Guapimirim, Vale do Rio Soberbo, 22.II.2011, fr., B. Neves et al. 7 (R). Teresópolis, estrada Rio- Teresópolis, Serra dos Órgãos, XII.1891, fr., E. Ule 1984 (R); PARNASO, sub-sede, 21.X.1977, fl., G. Martinelli 3333 (RB); sede, 04.IX.2012, fr., I. Kessous et al. 31 (R).

6. Aechmea weilbachii Didr., Ann. Sci. Nat., Bot. IV. 2: 375. 1854

Fig. $1 \mathrm{~g}$

Planta florida 40-50 cm, epífita. Roseta formando tanque, infundibuliforme. Folhas suberetas; bainha 7-10 × 4,5-6 cm, estreitoelíptica a elíptica, verde a alva, indumento lepidoto castanho; lâmina 16-30 × 1,6-3,5 cm, linear a estreito-elíptica, margem esparsamente serrilhada a serrilhada, ápice atenuado e acuminado, verde, indumento lepidoto muito esparso, alvo. Inflorescência terminal, pêndula, dupla espiga heterotética, estrobiliforme, laxa, 5,5-13 × 2,5-6,5 $\mathrm{cm}$; pedúnculo vermelho, pendente, $27-40 \times$ $0,2-0,4 \mathrm{~cm}$, indumento lanuginoso alvo; brácteas do pedúnculo não foliáceas, vermelhas, eretas, imbricadas, mais longas que os entrenós, as medianas 3-5,5 × 1-1,7 cm, estreito-elípticas, ápice atenuado e acuminado-pungente, margem inteira, indumento lanuginoso esparso; ramos suberetos, raque geniculada, brácteas estéreis no ápice dos ramos; brácteas primárias vermelhas, 2-3,5 × 0,6$1,5 \mathrm{~cm}$, mais longas que os pedúnculos, elípticas, ápice atenuado e pungente, margem inteira, indumento lanuginoso esparso; brácteas florais vermelhas, $0,5-0,8 \times 0,5-0,7 \mathrm{~cm}$, mais curtas que as sépalas, ovadas, ápice arredondado e apiculado, margem inteira ou esparsamente serrilhada, não carenadas, indumento lanuginoso. Flores polísticas, suberetas, não secundas, sésseis; sépalas $0,6-0,8$ 
$\times 0,5-0,7 \mathrm{~cm}$, arredondadas, assimétricas, ápice assimétrico, emarginado e apiculado, eretas, margem inteira, não carenadas, conatas em menos de $2 / 3$ do seu comprimento, verdes ou vermelhas, indumento lanuginoso; pétalas 1,5-1,6 × 0,5-0,6 $\mathrm{cm}$, espatuladas, ápice arredondado, cuculadas, livres, roxas, eretas, apêndices lingulados, $0,25 \mathrm{~cm}$; estames inclusos, $1,1-1,2 \mathrm{~cm}$, filetes filiformes, adnatos, anteras dorsifixas; ovário 0,8-0,9 × $05 \mathrm{~cm}$, ínfero, vermelho, arredondado, liso, placenta localizada em todo o lóculo, estigma róseo. Fruto baga.

Endêmica do estado do Rio de Janeiro, na Floresta Pluvial Tropical. Pertence à $A$. subg. Lamprococcus. São conhecidas, no Herbário $\mathrm{R}$, numerosas coletas realizadas nas décadas de 1950 e 1960, para a antiga Fazenda do Cortume, em Guapimirim, área vizinha ao PARNASO. No entanto, a espécie só foi registrada para os limites do parque durante o desenvolvimento do presente trabalho. Forma extensas populações epífitas no interior da mata, especialmente nas margens dos rios Bananal e Soberbo.

São descritas para a espécie duas variedades e três formas sendo reconhecida para o parque $A$. weilbachii var. weilbachii f. pendula Reitz. Além da inflorescência pêndula típica, o táxon se caracteriza pela inflorescência laxa, sépalas esverdeadas e corola azul (Sousa 2011).

Material selecionado: Guapimirim, PARNASO, 16.III.2012, fl., F.P. Uribbe 31 (R); Poço Verde, 24.VIII.2010, fr., J. Gomes-da-Silva 75 (R); Poço Verde, 20.III.2012, fr., L.F. Gonçalves et al. 71 (R); trilha do Poço Verde, PARNASO, 04.XI.2012, fr., F.P. Uribbe 60 et al. (R); Vale do Rio Bananal, Condomínio Monte Olivete, 23.VIII.2009, fr., A. Costa 884 (R). Magé, PARNASO, Serra da Estrela, 04.XI.2012, fr., F.P. Uribbe et al. $61(\mathrm{R})$; Santo Aleixo, picada do Córrego das Pedras Negras, 25.IX.2007, fr., M. Nadruz 2000 (RB). Petrópolis, Metade da Serra, 10.VIII.1968, fl., P.I.S. Braga 19 (RB). Teresópolis, Trilha do Rio Soberbo, 05.VII.2011, fl., L.F. Gonçalves 15 (R).

\section{Billbergia}

Apresenta cerca de 63 espécies (Luther 2012) distribuídas desde a América Central até o sul da América Meridional (Smith \& Downs 1979). Seus dois subgêneros, $B$. subg. Billbergia e $B$. subg. Helicodea, apresentam distribuição disjunta, o primeiro tem a Floresta Atlântica como centro de diversidade, e o segundo, a Floresta Amazônica (Smith \& Downs 1979). Das espécies ocorrentes no PARNASO, B. zebrina é a única representante do subgênero Helicoidea. $\mathrm{O}$ gênero, apesar de bem representado em número de espécies no parque, conta com poucos registros nos herbários, sendo três de suas espécies referenciadas por poucos indivíduos nas coleções. Billbergia iridifolia (Neees \& Mart.) Lindl. foi referenciada para a Serra da Estrela (Smith \& Downs 1979) porém o material depositado no Herbário $F$ não foi localizado e a espécie não foi recoletada durante o desenvolvimento do projeto.

7. Billbergia amoena (Lodd.) Lindl., Bot. Reg. 13: sub t. 1068. 1827.

Fig. $1 \mathrm{j}$

Planta florida $25-55 \mathrm{~cm}$ altura, epífita, terrestre ou rupícola. Roseta formando tanque, infundibuliforme. Folhas suberetas a arqueadas; bainha $11-13 \times 4,5-8 \mathrm{~cm}$, elíptica a estreito-elíptica, alva com mancha vinácea, indumento lepidoto; lâmina $16-45 \times 2-5,5 \mathrm{~cm}$, linear-lanceolada a lanceolada, margem com acúleos $0,5-1,5 \mathrm{~mm}$, ápice agudo ou obtuso, arredondado, verde ou vinácea, face abaxial com faixas transversais de indumento lepidoto alvo, ou não. Inflorescência terminal, ereta a subereta, espiga ou dupla espiga, laxa, $8-20 \times 7-15 \mathrm{~cm}$; pedúnculo verde a róseo, ereto a subereto, $20-36 \mathrm{~cm}$, indumento lepidoto esparso a glabro; brácteas do pedúnculo róseas ou vermelhas, patentes, as superiores não cobrindo a inflorescência, 5,2-12 × 1,5-2,7cm, elípticas a largo-elípticas, ápice agudo ou obtusoarredondado, apiculado ou não; raque reta, glabra, brácteas primárias róseas ou vermelhas, $5,2-10 \times$ $1,5-3,5 \mathrm{~cm}$, elípticas a largo-elípticas, ápice agudo ou obtuso-arredondado, apiculado, margem inteira, lepidota; brácteas florais verdes, vermelhas ou róseas geralmente com apículo azul, minutas até ca. $5 \mathrm{~mm}$, oblongas a deltoides, ápice apiculado ou caudado. Flores polísticas, suberetas, sésseis; sépalas $1,9-3 \times 0,5-0,7 \mathrm{~cm}$, oblongas a oblongolanceoladas, simétricas e raro assimétricas, ápice agudo ou obtuso-arredondado, raro oblíquo, apiculado ou não, margem inteira, não carenadas, curto-conatas, verdes com ápice azul, indumento lepidoto esparso; pétalas 4-5,3 $\times 0,65 \mathrm{~cm}$, lineares a espatuladas, ápice obtuso-arredondado, livres, totalmente verdes ou verdes com ápice azul, recurvadas, glabras, apêndices semi-cupuliformes, 1,5-2 $\mathrm{mm}$; estames exsertos por ca. de $1,5 \mathrm{~cm}$, filetes filiformes, adnatos, anteras dorsifixas; ovário cilíndrico, sulcado a fortemente sulcado, verde, placentação mediano-superior, estigma verde ou azul. Fruto baga. 
Distribui-se nos estados de Goiás, Bahia, Minas Gerais, Espírito Santo, Rio de Janeiro, São Paulo, Paraná e Santa Catarina, na Floresta Pluvial Atlântica, restinga, campos de altitude e campos rupestres.

Trata-se de uma espécie polimórfica, especialmente na forma da roseta, folhas e inflorescência, e coloração das sépalas e pétalas. Por este motivo, optou-se neste trabalho, por adotar a taxonomia a nível específico. No PARNASO, sua ocorrência foi registrada para Petrópolis e Teresópolis.

Material selecionado: Petrópolis, Mata do Príncipe, 19.XI.1967, fl., P.I.S. Braga 14 (HB); Retiro, Serra dos Órgãos, s.d., fl., V. Luetzelburg 7259 (RB); Serra da Estrela, s.d., fl., E. Pereira 10624 (HB); Serra da Estrela, s.d., fl., I. Penna 3 (HB). Teresópolis, Guarani, 04.X.1929, fl., A.C. Brade 9581 (R); Parque Nacional da Serra dos Órgãos, 10.V.1981, bt., R. Ribeiro 147 (GUA); trilha da Agulhinha do Beija- Flor, 13.IX.2011, fl., L.F. Gonçalves $24(\mathrm{R})$.

8. Billbergia horrida Regel, Ind. Sem. Hort. Petrop. For 1856: 17. 1857.

Planta florida 36-78 cm altura, epífita ou rupícola. Roseta formando tanque, tubular. Folhas eretas a suberetas; bainha $12-17 \times 4,6-8,5 \mathrm{~cm}$ elíptica a largo-elíptica, indumento lepidoto castanho; lâmina 24-36 × 5-6cm, linear-lanceolada a oblanceolada, base marcada com uma dobra, margem com acúleos 2-5 mm nigrescentes, ápice agudo a obtuso-arredondado, pungente, verde, glabra. Inflorescência terminal, ereta, espiga, laxa, 16-19 × 6-8 cm; pedúnculo verde, ereto, 20-58 $\mathrm{cm}$, glabro; brácteas do pedúnculo verdes a pardas, suberetas a patentes, as superiores não cobrindo a inflorescência, $8,5-10 \times 1,5-1,8 \mathrm{~cm}$, estreitoelípticas ápice agudo; raque reta, indumento lepidoto esparso a glabra, verde; brácteas florais verdes a pardas, inferiores e superiores $1-9 \mathrm{~mm}$, triangulares a ovadas, ápice agudo com ou sem tricomas, margem inteira. Flores polísticas, suberetas, sésseis; sépalas $1,5-1,7 \times 0,3-0,4 \mathrm{~cm}$, oblongo-obovadas, assimétricas, ápice subtruncado, oblíquo, margem inteira, não carenadas, livres, glabras; pétalas 4,2-4,5 ×0,3-0,6cm, espatuladas, ápice obtuso-arredondado, livres, brancas ou verdes, fortemente recurvadas, apêndices semicupuliformes levemente fimbriados, 1,5-2,2 mm; estames exsertos ca. $2 \mathrm{~cm}$, isodínamos, filetes filiformes, adnatos, anteras dorsifixas; ovário cilíndrico, sulcado, verde, placentação medianosuperior, estigma verde. Fruto não observado.
A espécie ocorre nos estados de Minas Gerais, Espírito Santo, Rio de Janeiro e Bahia, na Floresta Pluvial Atlântica até 1.050 metros de altitude. Possui dois registros para o PARNASO, na Serra da Estrela, localidade bem coletada há décadas atrás. Hoje o local é pouco explorado por pesquisadores por encontrar-se em área de risco.

Material selecionado: Petrópolis, Serra da Estrela, s.d., fl., J.G. Kuhlmann et al. 13106 (RB).

9. Billbergia pyramidalis (Sims) Lindl., Bot. Reg. 13: sub t. 1068. 1827.

Fig. 1h

Planta florida $40-50 \mathrm{~cm}$ altura, terrestre ou rupícola. Roseta formando tanque, infundibuliforme. Folhas arqueadas; bainha $10-15,5 \times 4,5-7,2 \mathrm{~cm}$, elíptica, alva, indumento lepidoto castanho; lâmina $25-40 \times 3,4-6 \mathrm{~cm}$, lanceolada, margem com acúleos ca. $0,5 \mathrm{~mm}$, ápice agudo apiculado, pungente, verde, face abaxial com faixas transversais de indumento lepidoto alvo, ou não. Inflorescência terminal, ereta, espiga, piramidal, laxa, 5-18 × 3,3-10 cm; pedúnculo branco, ereto, $26-47 \mathrm{~cm}$, indumento lanuginoso alvo; brácteas do pedúnculo róseas, suberetas a patentes, as superiores suberetas, cobrindo $1 / 2$ da inflorescência, 5-10 × 1,1-2,2cm, elípticas a largo-elípticas, ápice agudo; raque reta, indumento lanuginoso alvo; brácteas florais róseas, inferiores ca. $0,8 \mathrm{~mm}$, as superiores minutas ou ausentes. Flores polísticas, suberetas, sésseis a curto-pediceladas, sépalas 1,3-2 × 0,6-1 $\mathrm{cm}$, oblongas a obovadas, assimétricas, ápice obtuso-arredondado, oblíquo, margem inteira, não carenadas, livres, róseas, indumento lanuginoso alvo; pétalas 4,3-5 × 0,9 cm, espatuladas, ápice obtuso-arredondado, livres, vermelhas com ápice roxo, recurvadas, apêndices semi-cupuliformes, irregularmente fimbriados a lacerados, 2-2,7 mm; estames exsertos por 1,4-1,7 cm, isodínamos, filetes filiformes, adnatos, anteras dorsifixas; ovário subcilíndrico a cilíndrico, liso a levemente sulcado, branco, placentação mediano-superior, estigma lilás. Fruto baga.

A espécie distribui-se pelos estados da Bahia, Minas Gerais, Espírito Santo, Rio de Janeiro e São Paulo na Floresta Pluvial Atlântica. No PARNASO, ocorre nos municípios Guapimirim, Petrópolis e Teresópolis.

Material selecionado: Guapimirim, Dedo de Nossa Senhora, 20.11.2009, fl., C. França (R 212.377); Fazenda Barreira, 20.XI.1932, fl., A.C. Brade 12083 (R); Vale do Rio Bananal, Condomínio Monte Olivete, 23.VIII.2009, fl., A. Costa et al. 881 (R). Magé, próximo à cachoeira 
do Monjolo, 19.X.2010, fl., R. Moura et al. 988 (R). Petrópolis, estrada velha de Petrópolis, 10.IV.1952, fl., L.B. Smith 6495 (US). Teresópolis, caminho para Pedra do Sino, 21.X.1977, fl., G. Martinelli 3315(RB). S. loc., Serra dos Órgãos, XII.1891, fl., E. Ule (R 46427); Serra dos Órgãos, Pico Majestoso, 27.XI.1942, fl., E. Pereira 261 (RB); 8.IX.1968, fl., G.F.J. Pabst 8978 (US).

10. Billbergia sanderiana E. Morren, Belgique Hort. 34: 17-19, pls. 1-2. 1884.

Planta florida $40-50 \mathrm{~cm}$ altura, epífita. Roseta formando tanque, infundibuliforme. Folhas suberetas a arqueadas; bainha $15-20 \times 8-9,5 \mathrm{~cm}$; lâmina 23-30 × 4,5-6 cm, lanceolada a levemente obovada estreitando em direção à base, margem com acúleos $2-7 \mathrm{~mm}$, nigrescentes, ápice agudo ou obtuso arredondado, pungente, verde, glabra. Inflorescência terminal, pendente, espiga dupla, largo-elíptica a elíptica, laxa na base e congesta em direção ao ápice, $28-35 \times 12-15 \mathrm{~cm}$; pedúnculo verde ou róseo, pendente, $24-33 \mathrm{~cm}$, indumento lepidoto esparso a glabro; brácteas do pedúnculo róseas, as superiores pardas na antese, suberetas, 6-7 × 2-4 cm, largo-elípticas, margem serrada, ápice agudo, apiculado; raque reta, indumento lepidoto esparso a glabra, verdes ou róseas; brácteas primárias, 6,5-7 × 3-3,5 cm, largo-elípticas, ápice agudo, apiculado, margem serrada ou inteira, indumento lepidoto; brácteas florais róseas ou azuis, $0,5-1,2 \times 0,3-0,6 \mathrm{~cm}$, oblongo-lanceoladas a elípticas, ápice acuminado a arredondado, com ou sem apículo. Flores inferiores patentes a reflexas e superiores suberetas a patentes, sésseis; sépalas $2-2,2 \times 0,6-0,7 \mathrm{~cm}$, oblongo-lanceoladas, simétricas ou assimétricas, ápice agudo ou obtuso arredondado, apiculado, margem inteira, livres, com base rósea, porção mediana branca e ápice azul; pétalas 4,5-5 ×3,5-4 cm, lineares a levemente espatuladas, ápice obtuso-arredondado, livres, verdes com ápice azul, recurvadas, apêndices semicupuliformes, levemente fimbriados, ca. 2 $\mathrm{mm}$; estames exsertos por ca. $1,4 \mathrm{~cm}$, isodínamos, anteras dorsifixas; ovário cilíndrico, fortemente sulcado, verde, placentação ao longo de todo o lóculo, estigma roxo. Fruto não observado.

A espécie distribui-se pelos estados de Minas Gerais, Rio de Janeiro e Espírito Santo, na Floresta Pluvial Atlântica. Foi coletada em Petrópolis e Teresópolis.

Material selecionado: Petrópolis, 23.VII.1968, fl., P.I.S. Braga 24 (RB). Teresópolis, PARNASO, s.d., fl., Leme 1870 (HB); 1952, fl., J. Vidal II-2236 (R); PARNASO, Cascata do Imbuí, s.d., fl., A. Sampaio 2696 (R).
11. Billbergia zebrina (Herb.) Lindl., Bot. Reg. 13: sub t. 1068. 1827.

Fig. 1i

Planta florida $39-50 \mathrm{~cm}$ altura, epífita. Roseta formando tanque, tubular. Folhas eretas; bainha $16-22 \times 5,5-6,5 \mathrm{~cm}$, elíptica, indumento lepidoto castanho; lâmina 50,5-64 × 4,6-5cm, lanceolada, margem com acúleos $1 \mathrm{~mm}$, ápice obtuso-arredondado, pungente, verde, face abaxial com faixas transversais de indumento lepidoto alvo. Inflorescência terminal, pendente, espiga, laxa, 13-19 cm; pedúnculo pendente, $48-52 \mathrm{~cm}$, verde, indumento lanuginoso alvo; brácteas do pedúnculo róseas, suberetas a patentes, as superiores cobrindo até $2 / 3$ da inflorescência, $12-14 \times 2,3-3 \mathrm{~cm}$, largo-elípticas, ápice agudo; raque reta, indumento lanuginoso alvo; brácteas florais inferiores e superiores ca. $0,6 \mathrm{~mm}$ ou ausentes, deltoides, ápice agudo, apiculado, indumento lanuginoso alvo. Flores polísticas, suberetas, sésseis, sépalas $5-5,5 \times 4,5-5 \mathrm{~mm}$, deltoides a ovadas, simétricas, ápice obtuso-arredondado, minutamente apiculado, margem inteira, não carenadas, livres, cremeesverdeadas, alvo lanuginosas; pétalas $6,5 \times$ 0,3-0,6 cm, lineares a oblanceoladas, ápice agudo, livres, creme-esverdeadas com ápice azul, revolutas, glabras, apêndices semi-cupuliformes, 1,9-2,2 cm; estames azuis, exsertos por 4,5-5,5 $\mathrm{cm}$, isodínamos, filetes complanados, anteras basifixas; ovário turbinado, fortemente sulcado, placentação mediana a mediano superior, estigma azul. Fruto baga.

A espécie ocorre na Bahia, Minas Gerais, Rio de Janeiro, São Paulo, Paraná, Santa Catarina e Rio Grande do Sul, na Floresta Pluvial Atlântica e nas matas de restinga, no Cerrado e campos rupestres, até $1.100 \mathrm{~m}$ de altitude. Sua distribuição se interioriza ao sul do país até o Paraguai e a Argentina. No Rio de Janeiro ocorre nas matas de restinga e em florestas baixo montanas e montanas, do nível do mar até cerca de 800 m.s.m. Foi registrada sua ocorrência em Guapimirim e Petrópolis, nos limites do PARNASO.

Material selecionado: Guapimirim, PARNASO, trilha do Miudinho, 22.II.2011, fl., B. Neves et al. 3 (R). Petrópolis, Rio-Petrópolis, 26.VI.1988, fl., G. Martinelli et al. 12975 (RB).

\section{Hohenbergia}

Conta com 65 espécies (Luther 2012) divididas em dois subgêneros que se diferenciam pelo formato dos óvulos e coloração das pétalas (Smith \& Downs 1979). H. subg. Hohenbergia 
está distribuído em Trinidad e Tobago, Venezuela, Colômbia e Brasil. Já H. subg. Wittmackiopsis tem ocorrência restrita ao Caribe. No Brasil ocorrem 47 espécies, das quais 46 (98\%) são endêmicas do país, tendo a Mata Atlântica como principal centro de diversidade (Forzza et al. 2014). No PARNASO, o gênero é representado por uma única espécie, H. augusta, que apresenta distribuição ampla, ocorrendo desde o estado do Espírito Santo até Santa Catarina. Apesar de o gênero ter a Mata Atlântica como grande centro de diversidade (33 spp.), apenas duas espécies ocorrem no estado do Rio de Janeiro.

\section{Hohenbergia augusta (Vell.) E. Morren, Catal.:} 9. 1873.

Planta florida 70-130 cm altura, epífita ou terrestre. Roseta formando tanque, infundibuliforme. Folhas suberetas; bainha 17-27 × 7-14, elíptica, verde clara a alva; lâmina 70-105 × 6-6,5 cm, lingulada, ápice arredondado a agudo, pungente, margem esparsamente serrilhada até inteira no ápice e densamente serrilhada a esparsamente serrilhada na base, acúleos até $2 \mathrm{~mm}$, antrorsos, patentes ou retrorsos, verde, muitas vezes com manchas verde-escuras. Inflorescência terminal, ereta, composta com ramificações de terceira ordem, 28-55cm, piramidal, indumento lanuginoso castanho; pedúnculo verde, ereto, $50-70 \mathrm{~cm}$, indumento lanuginoso castanho; brácteas do pedúnculo verdes com base arroxeada, 5-10 × 2,5-6 cm, oblongas a lanceoladas, ápice agudo, margem inteira, indumento lanuginoso esparso; ramos patentes a suberetos; brácteas primárias, 2-7× $1-2,2 \mathrm{~cm}$, triangulares a lanceoladas, margem inteira, indumento lanuginoso esparso; brácteas secundárias mais curtas até igualando as espigas, triangulares, margem inteira; espigas subsésseis, globosas a ovoides; brácteas florais ca. $8 \mathrm{~mm}$, suborbiculares, levemente nervadas, ápice arredondado, apiculado, margem inteira. Flores polísticas, sésseis; sépalas verdes, ca. 4,5 mm, assimétricas, conatas ca. 0,5mm, ápice apiculado, margem inteira; pétalas ca. $7 \mathrm{~mm}$, verdes com base arroxeada, linguladas, estames inclusos; ovário obcônico, liso, tubo epíginico inconspícuo. Fruto baga.

Planta endêmica do Brasil, ocorrendo nos estados do Espírito Santo, Rio de Janeiro, São Paulo, Paraná e Santa Catarina. No PARNASO, é encontrada como epífita, ocorrendo isoladamente e em forófitos de grande altura, por isso a grande dificuldade de coletá-la. Foi registrada em fruto em setembro.
Material selecionado: Guapimirim, PARNASO, 04.IX.2012, fr., C. Schittini et al. 04 (R). S. loc., Serra dos Órgãos, 1952, fr., J. Vidal II 2152 (R).

\section{Quesnelia}

É constituído por 23 espécies (Luther 2012), todas endêmicas da costa leste brasileira, nos domínios da Mata Atlântica. Está dividido em dois subgêneros: Quesnelia subg. Quesnelia e Q. subg. Billbergiopsis (Smith \& Downs 1979). No PARNASO, com exceção de $Q$. quesneliana, todas pertencem à $Q$. subg. Billbergiopsis. As espécies $Q$. liboniana e $Q$. lateralis são frequentes e abundantes na unidade de conservação, estando bem representadas nos herbários. Esta última, junto com Q. edmundoi var. edmundoi são endêmicas do estado do Rio de Janeiro.

\section{Quesnelia edmundoi L.B.Sm. var. edmundoi,} Smithsonian Misc. Collect. 126(1): 34. 1955.

Planta florida 55-91 cm altura, epífita. Roseta formando tanque, tubular. Folhas suberetas; bainha 14-19 × 8,8-11,5cm, largo-elíptica, roxa na face adaxial, indumento lepidoto denso alvo em ambas as faces; lâmina 27-28 × 3,5-4,7cm, lanceolada, margem serrilhada com acúleos robustos, ápice apiculado a raro levemente arredondado, pungente, verde, indumento lepidoto denso alvo em ambas as faces. Inflorescência terminal, ereta, espiga, estrobiliforme, congesta, 7,7-18,0 × 4,6-5,5cm; pedúnculo verde, ereto, $47,5-73,0 \times 0,6-0,7 \mathrm{~cm}$, indumento lepidoto denso castanho; brácteas do pedúnculo esverdeadas, eretas, 6,2-9,0 × 2,3cm, estreito-oblongas, ápice acuminado, pungente, inferiores com margem serrilhada e medianas e superiores com margem inteira, indumento lepidoto denso castanho na face abaxial; brácteas florais amarelo-esverdeadas, inferiores 2,8-3,0 × 1,6-1,8cm, mais longas que as sépalas, elípticas, ápice obtuso, acuminado, incurvado, margem inteira, lisa, não carenadas, cuculadas, glabras. Flores polísticas, eretas, não secundas, sésseis; sépalas 1,5-1,8 $\times$ $0,7 \mathrm{~cm}$, oblongas, levemente assimétricas, ápice obtuso, eretas, carenadas, livres, albo-amareladas, glabras; pétalas 2,0-2,2 × 0,5-0,6 cm, oblongas a sub-obovadas, ápice arredondado, cuculadas, livres, albo-amareladas, eretas, glabras, apêndices petalíneos longo-espatulados, irregularmente dentados no ápice, 8,0-9,0 × 1,5-2,0mm; estames inclusos, 2,3-2,5cm, filetes complanados, anteras inclusas, dorsifixas; ovário subtrígono, creme, liso, placenta na porção mediana do ovário, estigma alvacento. Fruto baga. 
Endêmica do estado do Rio de Janeiro. Habita a Floresta Pluvial Tropical, em altitudes até 400 m.s.m. Floresce em outubro e novembro e frutifica de janeiro a março. No PARNASO, foi registrada no município de Petrópolis como epífita. Sua presença também foi verificada na Estação Ecológica Estadual do Paraíso em Guapimirim, entorno do parque.

Material selecionado: Petrópolis, Serra da Estrela, 1.I.1968, fr., E. Pereira 10651 (HB); 5.X.1971, fl., E. Pereira (HB 52531).

14. Quesnelia lateralis Wawra, Oesterr. Bot. Z. 30: 149. 1880.

Fig. 11

Planta florida $30-74 \mathrm{~cm}$ altura, saxícola, rupícola, epífita e terrestre. Roseta formando tanque, de tubular a estreito-infundibuliforme. Folhas suberetas a recurvadas; bainha 13-18 $\times$ $4,0-9,5 \mathrm{~cm}$, elíptica a oblonga, roxa na face adaxial e alva na face abaxial, indumento lepidoto alvo a castanho denso em ambas as faces; lâmina de $28-78 \times 3,2-6,3 \mathrm{~cm}$, estreito-oblonga, margem serrilhada com acúleos castanho-escuros, ápice arredondado, pungente, verde, indumento lepidoto denso alvo a geralmente castanho em ambas as faces. Inflorescência lateral ou raro terminal, ereta a subereta, espiga, fusiforme, congesta, 3,7-10,5 $\times 2,0-2,5 \mathrm{~cm}$; pedúnculo verde, ereto a subereto, $20,0-67,5 \times 0,2-0,3 \mathrm{~cm}$, indumento lanuginoso esparso a denso; brácteas do pedúnculo vermelhas, eretas, $10,7-4,5 \times 1,2 \mathrm{~cm}$, estreito-elípticas, ápice agudo, acuminado, reto, margem inteira, indumento lepidoto denso a raramente esparso, alvo na face abaxial; brácteas florais vermelhas, 2,5-4,0 $\times$ $1,2 \mathrm{~cm}$, mais longas que as sépalas, ovais, ápice agudo, reto, margem inteira, lisas, não carenadas, indumento lepidoto denso a raramente esparso alvo na face abaxial. Flores polísticas, eretas, não secundas, sésseis; sépalas $1.2-1.6 \times 0.5 \mathrm{~cm}$, oblongas, levemente assimétricas, ápice obtuso, não carenadas, margem inteira, membranáceas, conatas, vermelhas, indumento glabro na face abaxial; pétalas $3,8 \times 0,7 \mathrm{~cm}$, espatuladas, ápice obtuso, pouco recurvo na antese, não cuculadas, membranáceas, alvas na base e azuis no ápice, eretas, glabras, apêndices ligulados, fimbriados no ápice, 0,4-0,1 cm; estames alvos, inclusos, ca. $3,4 \mathrm{~cm}$, filetes complanados, antera dorsifixa; ovário cilíndrico, liso, placenta ocupando $2 / 3$ superiores do lóculo, estigma azul. Fruto baga.

Espécie nativa e endêmica do Rio de Janeiro. Habita a Floresta Pluvial Tropical, sendo encontrada em altitudes que variam de 850 a 2.100 m.s.m. Florescem ao longo do ano todo, seus frutos foram registrados em abril e setembro. No PARNASO, Q. lateralis é encontrada nos municípios de Guapimirim, Petrópolis e Teresópolis, possui uma distribuição ampla e forma populações de muitos indivíduos. A espécie foi bastante coletada na trilha da Pedra do Sino. Ocorre nas florestas montanas que abrangem a maior área do Parque, e na altomontana chegando a atingir 2.100 m.s.m.

Material selecionado: Guapimirim, sub-sede, 18.XII.1972, fl., B. Flaster (R 164198). Petrópolis, estrada Itaipava-Teresópolis, 21.IV.1968, fl., P.I.S. Braga 4 (RB); Rocio, mata do Facão, 25.IV.1986, fl., G. Martinelli 11571 (RB). Teresópolis, 22.VIII.1940, fl., M. \& R. Foster 992 (GH, US); caminho para Pedra do Sino, 27.IV.1977, fl., G. Martinelli 1720 (RB); entre barragem e abrigo II, 28.IV.1962, fl., G.F.J. Pabst 6957 (HB); Pedra Chapadão, VII.1940, fl., A.C. Brade 16694 (RB); sede do PARNASO, 31.VII.1960, fl., B. Flaster 74 (R); Serra dos Órgãos, X.1896, fl., E. Ule 4138 (R). s. loc., Serra dos Órgãos (Parque Nacional), 3.X.1952, fl., F. Markgraf 10114 (Z); 11.VII.1956, fl., A. Castellanos 21651 (US).

15. Quesnelia liboniana (De Jonghe) Mez, Bot. Arch. 1: 66. 1922.

Fig. $1 \mathrm{~m}$

Planta florida 33-59 cm altura, epífita ou terrestre. Roseta formando tanque, tubular. Folhas suberetas a recurvadas; bainha $11-17 \times 6-7,5 \mathrm{~cm}$, elíptica, vinosa na face adaxial, indumento lepidoto alvo a castanho denso em ambas as faces; lâmina de $33,5-52,0 \times 2,5-5,5 \mathrm{~cm}$, linear-triangular, margem serrilhada com acúleos castanhos, ápice agudo, pungente, verde escuro, indumento lepidoto denso castanho escuro a alvo em ambas as faces. Inflorescência terminal, ereta a subereta, espiga, laxa, $13,5-4,2 \mathrm{~cm} \times 7,2-2,3 \mathrm{~cm}$; pedúnculo verdeclaro, ereto a subereto, $24,5-50,0 \times 0,1-0,2 \mathrm{~cm}$, indumento lanuginoso esparso a denso; brácteas do pedúnculo verdes, eretas, $3,0-6,8 \times 0,3-1,0 \mathrm{~cm}$, estreito-triangulares, ápice agudo, reto, margem inteira, indumento lepidoto denso a alvo na face abaxial; brácteas florais vermelhas, inferiores $1,5-3,5 \times 0,3-0,9 \mathrm{~cm}$ e superiores $0,5-1,3 \times 0,3-$ $0,5 \mathrm{~cm}$, mais curtas que as sépalas, triangulares, ápice agudo, reto, margem inteira, lâmina lisa, não carenadas, indumento lepidoto denso a raramente esparso alvo na face abaxial. Flores suberetas, polísticas, não secundas, sésseis; sépalas ca. $2,0 \times 0,6 \mathrm{~cm}$, oblongas, levemente assimétricas, ápice obtuso, acuminado, margem inteira, não carenadas, curto-conatas, vermelhas, indumento 
glabro na face abaxial; pétalas ca. 4,1 ×0,7cm, espatuladas, ápice obtuso, sub-recurvo na antese, não cuculadas, membranáceas, azuis a roxas, eretas, alvacentas em direção a base, glabras, apêndices lingulados, fimbriados no ápice, ca. $0,2 \times 0,2 \mathrm{~cm}$; estames alvos, inclusos, ca. $3,5 \mathrm{~cm}$, filetes complanados, anteras dorsifixas; ovário cilíndrico, liso, placenta fixada na porção mediana do ovário, estigma roxo. Fruto baga, vermelho.

Planta endêmica da Mata Atlântica. Habita a Floresta Pluvial Tropical e Floresta Estacional Mesófila Semi-decidual, em altitudes até 1.300 m.s.m. Floresce o ano todo, com maior frequência nos meses de junho a novembro. Frutifica de agosto a fevereiro. Ocorre nos estados de Minas Gerais, São Paulo e Rio de Janeiro. Há registros da espécie nos quatro municípios ocupados pelo PARNASO, sendo bem distribuída na unidade de conservação e abundante formando populações grandes. Foi observada em altitudes que variam de 420 a 1.300 m.s.m., ocorrendo nas partes baixas e do entorno do parque, floresta pluvial baixo-montana, como também nas de maiores altitudes, na floresta montana.

Material selecionado: Guapimirim, próximo ao Museu Martius, 21.X.1977, fl., G. Martinelli 3331 (RB). Magé, Serra da Estrela. 9.X.1967, fl., E. Pereira 10632 (HB). Petrópolis, Corrêas, IX.1943, fl., O.C. Goés \& D. Constantino 611 (US); road PetrópolisRaiz da Serra, 23.XI.1928, L.B. Smith 1325 (S); Rocio, 28.I.1968, f1., D. Sucre 2263 (RB). Teresópolis, VI.1956, fl., A. Abendroth 6, 7 (US); Serra do Órgãos, XII.1891, fl., E. Ule (R 46428); Serra dos Órgãos, Dedo de Nossa Senhora, 1.I.1966, fl., P. Carauta 295 (GUA); Soberbo, 20.X.1963, fl., G.F.J. Pabst (HB 28120); trilha da Agulha do Beija-flor, 23.II.2011, fl., B. Neves 10 (RB); Vale do Rio Bananal, 23.VIII.2009, fl., A. Costa 886 (R).

16. Quesnelia quesneliana (Brongn.) L.B.Sm., Arch. Bot. de São Paulo 2: 196. 1952. Fig. 1n Planta florida $55-56 \mathrm{~cm}$ altura, epífita, rupícola ou terrestre. Roseta formando tanque, largo-infundibuliforme. Folhas suberetas a recurvadas; bainha $9-13 \times 4,5-6,5 \mathrm{~cm}$, elíptica a oblonga, vinosa na face adaxial, indumento lepidoto alvo a castanho, denso em ambas as faces; lâmina $23-17 \times 3,0-4,5 \mathrm{~cm}$, estreito-eliptica a estreito-triangular, margem serrilhada com acúleos castanho-escuros, ápice agudo, pungente, verde discolor com bandas transversais alvacentas na face abaxial, indumento lepidoto denso, alvo a castanho em ambas as faces. Inflorescência terminal, ereta a subereta, espiga, estrobiliforme, congesta, $11,0-12,5 \times 4,5-5,5 \mathrm{~cm}$; pedúnculo alvo, ereto a subereto, ca. $44 \times 0,5 \mathrm{~cm}$, indumento lanuginoso alvo, denso; brácteas do pedúnculo inferiores foliáceas, superiores estramíneas, eretas, 14,5 $\times 2,8 \mathrm{~cm}$, ovado-lanceoladas a elípticas, ápice agudo, pungente, superiores com margem inteira e inferiores com margem serrilhada, indumento lepidoto denso a esparso, alvo a castanho na face abaxial; brácteas florais róseo-avermelhadas, inferiores $4,0 \times 1,3-1,9 \mathrm{~cm}$ e superiores ca. 2,6 6 $1,0 \mathrm{~cm}$, mais longas que as sépalas, oblongas, ápice arredondado, margem inteira, lâmina crispada na margem, não carenadas, indumento lanuginoso denso a esparso, alvo em ambas as faces. Flores polísticas, eretas, não secundas, sésseis; sépalas $1,0-1,6 \times 0,8-1,1 \mathrm{~cm}$, levemente assimétricas, oblongas, ápice arredondado a obtuso, não carenadas, margem serrilhada, membranáceas, conatas, róseas, indumento lanuginoso esparso; pétalas $2,3-2,8 \times 0,7-0,9 \mathrm{~cm}$, obovadas, ápice arredondado, cuculadas, brancas com ápice azul a roxo, eretas, indumento lanuginoso esparso na face abaxial, apêndices espatulados, ca. 2,5-5,0 × 1,5-2,0mm; estames inclusos, $2,4-3,0 \mathrm{~cm}$, filetes complanados, anteras dorsifixas; ovário subtrígono, liso, placenta na porção mediana do ovário, estigma alvacento. Fruto baga.

Espécie nativa e endêmica dos estados de Minas Gerais, Espírito Santo e Rio de Janeiro. Habita a Floresta Pluvial Tropical, Floresta Estacional Mesófila Semidecídua, Restinga e Mangue. Ocorre em altitudes até 700 m.s.m. Seu período de floração vai de junho a outubro, frutificando de setembro a dezembro. No PARNASO, suas populações apresentam poucos indivíduos. Foi registrada somente nos municípios de Guapimirim e Petrópolis atingindo altitudes de até 500 m.s.m. na floresta pluvial baixo-montana.

Material selecionado: Guapimirim, 15.VIII.1981, f1., G. Martinelli 7641 (RB); Barreira, VI.1953, fl., J. Vidal II-6762 (R); PARNASO, trilha do Rio Soberbo, 23.III.2012, fl., L.F. Gonçalves et al.75 (R). Magé, Parque Nacional da Serra dos Órgãos, Andorinhas, Vale do Rio Santo Aleixo 13.I.2012, fl., B. Neves et al. 25 (R). Petrópolis, Reserva Ecológica de Alcobaça, 10.XI.1997, fr., C. Vieira 1019 (RB).

Táxon Excluído: Aechmea organensis Wawra (ver observações sob $A$. coelestis). 

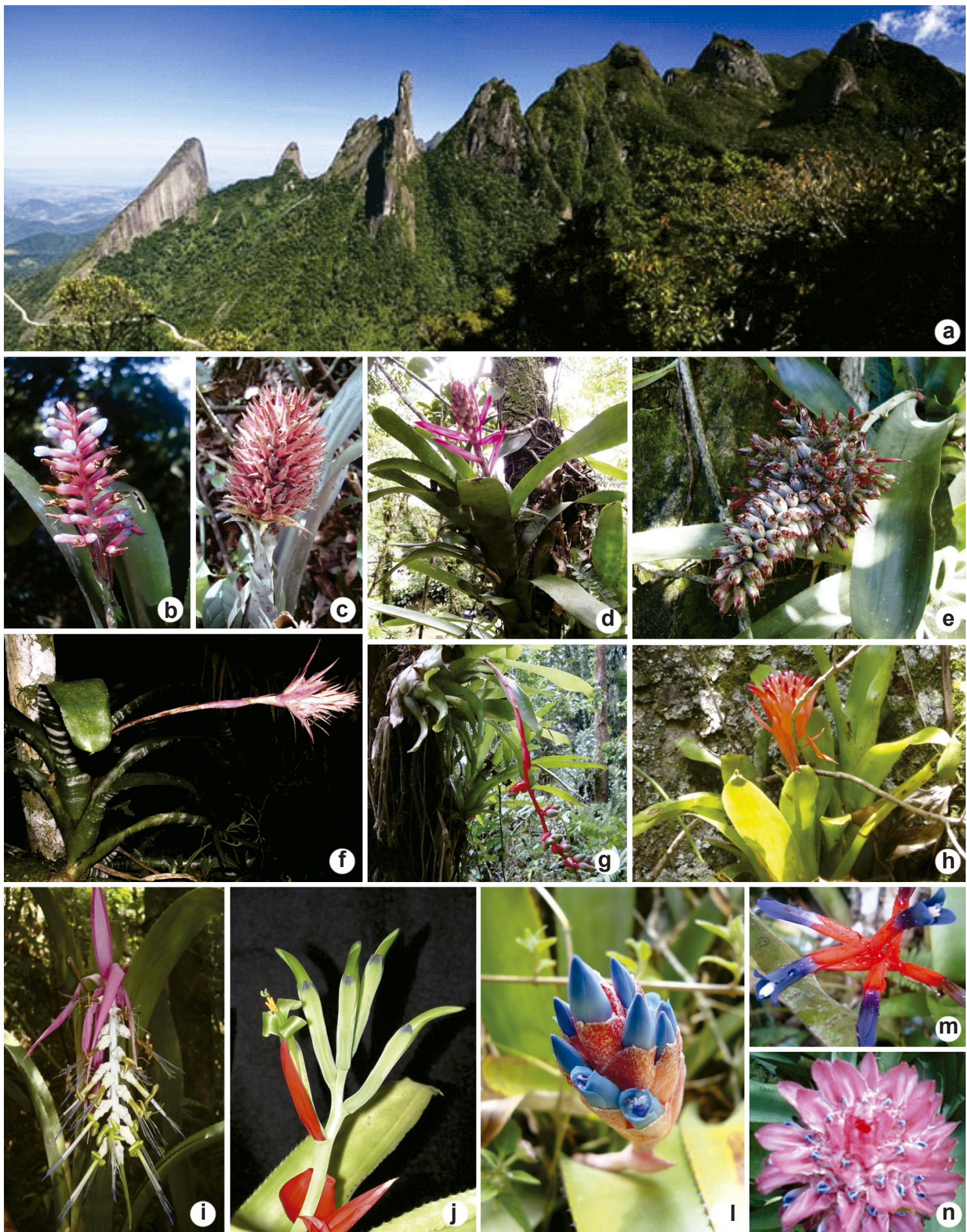

Figura 1- a. Serra dos Órgãos vista do mirante da Trilha do Cartão Postal, Teresópolis; b. Aechmea gracilis; c. A. pectinata; d. A. nudicaulis; e. A. coelestis; f. A. fasciata; g. A. weilbachii; h. Billbergia pyramidalis; i. B. zebrina; j. B. amoena; 1. Quesnelia lateralis; m. Q. liboniana; n. Q. quesneliana. Fotos: Beatriz Neves, Suara Jacques, Luís Fernando Gonçalves, Fernando Uribbe e Andrea Costa.

Figure 1-a. View of Serra dos Órgãos from the look out of Cartão Postal Track, Teresópolis; b. Aechmea gracilis; c. A. pectinata; d. A. nudicaulis; e. A. coelestis; f. A. fasciata; g. A. weilbachii; h. Billbergia pyramidalis; i. B. zebrina; j. B. amoena; 1. Quesnelia lateralis; $\mathrm{m}$. Q. liboniana; n. Q. quesneliana. Photos: Beatriz Neves, Suara Jacques, Fernando Gonçalves, Luís Fernando Uribbe and Andrea Costa. 


\section{Agradecimentos}

Ao $\mathrm{CNPq}$, os recursos e bolsas de estudos concedidos para BNFS e FPU através do edital Protax (processo \# 562187/2010-3), e a bolsa de produtividade em pesquisa a AFC (processo \# 307057/2011-9); à CAPES, as bolsas concedidas a RLM (Protax) e SSAJ; à Concessionária RioTeresópolis S/A (CRT), os recursos para as expedições no campo; à equipe de Pesquisa do PARNASO, especialmente a Cecília C. Faria; aos monitores Pheterson G. Oliveira e Ricardo L. Correia, o auxílio durante as coletas; à equipe do Bromeliaceae organensis, em especial a Luís Fernando G. Silva; ao Museu Nacional-UFRJ (Herbário e Setor de Transportes), o auxílio e infraestrutura; aos curadores dos herbários, o acesso, empréstimo e envio de imagens de seus acervos.

\section{Referências}

Almeida, V.R.; Costa, A.F.; Mantovani, A.; Gonçalves-Esteves, V.; Arruda, R.C.O. \& Forzza, R.C. 2009. Morphological Phylogenetics of Quesnelia (Bromeliaceae, Bromelioideae). Systematic Botany 34: 660-672.

Cronemberger, C. \& Viveiros-de-Castro, E. 2007. Ciência e conservação na Serra dos Órgãos. Instituto Chico Mendes de Conservação da Biodiversidade, Brasília. 298p.

Faria, A.P.G.; Wendt, T. \& Brown, G.K. 2004. Cladistic relationships of Aechmea (Bromeliaceae, Bromelioideae) and allied genera. Annals of the Missouri Botanical Garden 91:303-319.

Forzza, R.C.; Costa, A.F.; Siqueira-Filho, J.A.; Martinelli, G.; Monteiro, R.F.; Santos-Silva, F.; Saraiva, D.; Paixão-Souza, B.; Louzada, R.B. \& Versieux, L.M. 2014. Bromeliaceae. In: Lista de Espécies da Flora do Brasil. Jardim Botânico do Rio de Janeiro. Disponível em $<$ http://floradobrasil.jbrj. gov.br/jabot/floradobrasil/FB66>. Acesso em 16 outubro 2014.

Givnish, T.; Millan, K.; Berry, P. \& Sytsma, K. 2007. Phylogeny adaptative radiation, and historical biogeography of Bromeliaceae inferred from $n d h F$ sequence data. In: Columbus, J.T.; Friar, E.A.; Hamilton, C.W.; Porter, J.M.; Prince, L.M. \& Simpson, M.G. (eds.). Monocots: Comparative Biology and Evolution (3 vols.). Rancho Santa Ana Botanic Garden, Claremont. Pp. 3-26.

Givnish, T.; Barfuss, M.; Ee, B.; Riina, R.; Schulte, K.; Horres, R.; Gonsiska, P.; Jabaily, R.; Crayn, D.; Smith, A.; Winter, K.; Brown, G.; Evans, T.; Holst, B.; Luther, H.; Till, W.; Zizka, G.; Berry, P. \& Sytsma, K. 2011. Phylogeny, adaptive radiation, and historical biogeography in Bromeliaceae: insights from an eight-locus plastid phylogeny. American Journal of Botany 98: 872-895.

Goetze, M. 2014. Especiação e diversidade genética no subgênero Ortgiesia (Aechmea, Bromeliaceae). Tese de Doutorado. Universidade Federal do Rio Grande do Sul, Porto Alegre. 132p.

ICMBIO - Parque Nacional da Serra dos Órgãos (PARNASO) 2014. Disponível em <http://www. icmbio.gov.br/parnaso $>$. Acesso em 30 de outubro 2014.

Lindman, C.A.M. 1891. Bromeliaceae herbarii regnelliani.I - Bromelieae. Kongl. Boktryckeriet. P. A. Norstedt \& Soener, Stockolm. 50p.

Luther, H.E. 2012. An alphabetical list of bromeliad binomials. $13^{\mathrm{a}}$ ed. Marie Selby Botanical Gardens and Bromeliad Society International, Sarasota. 44p.

Martinelli, G.; Vieira, C.M.; Gonzalez, M.; Leitman, P.; Piratininga, A.; Costa, A.F. \& Forzza, R.C. 2008. Bromeliaceae da Mata Atlântica Brasileira: Lista de espécies, distribuição e conservação. Rodriguésia 59: 209-258.

Martins, S.; Wanderley, M.G.L. \& Proença, S.L. 2007. Bromeliaceae. In: Wanderley, M.G.L.; Shepherd, G.J.; Melhem T.S. \& Giulietti, A.M. Flora fanerogâmica do estado de São Paulo. Instituto de Botânica, São Paulo. Vol. 5, pp 39-161.

Moura, R.L.; Costa, A.F. \& Araujo, D.S.D. 2007. A família Bromeliaceae nas restingas fluminenses: florística e fitogeografia. Arquivos do Museu Nacional 65: 139-168.

Myers, N.; Mittermeier, R.; Mittermeier, C.; Fonseca G. \& Kent, J. 2000. Biodiversity hotspots for conservation priorities. Nature 403: 853-858.

Radford, A.E. 1986. Fundamentals of plant systematics. Harper \& Row, Publ. Inc., New York. 498p.

Reitz, R. 1983. Bromeliáceas e a Malária Bromélia Endêmica. In: Reitz, R. Flora Ilustrada Catarinense. Fasc. BROM. Herbário Barbosa Rodrigues, Itajaí. 59p.

Rizzini, C.T. 1954. Flora Organensis. Lista preliminar dos Cormophyta da Serra dos Órgãos. Arquivos do Jardim Botânico do Rio Janeiro 13: 117-246.

Rizzini, C.T. 1979. Tratado de Fitogeografia do Brasil - Aspectos Sociológicos e Florísticos. Vol. 2. HUCITEC/EDUSP, São Paulo. 374p.

Sass, C. \& Specht, C. 2010. Phylogenetic estimation of the core bromelioids with an emphasis on the genus Aechmea (Bromeliaceae). Molecular Phylogenetic Evolution 55: 559-571.

Scharf, U. \& Gouda, E. 2008. Bringing Bromeliaceae back to homeland botany. Journal of the Bromeliad Society 58: 123-129.

Smith, L.B. 1934. Geographical evidence on the lines of evolution. Botanische Jahrbücherfür Systematik, Pflanzengeschichte und Pflanzengeographie 66: 446-468. 
Smith, L.B. \& Downs, R.J. 1979. Bromelioideae (Bromeliaceae). Flora Neotropica Monograph 14: 1493-2141.

Sousa, L.O.F. \& Wendt, T. 2011. Revisão Taxônomica e Filogenia de Aechmea Ruiz \& Pav. subgênero Lamprococcus (Beer) Baker, Bromelioideae. Bromeliaceae. Tese de Doutorado. Universidade Federal do Rio de Janeiro - Museu Nacional, Rio de Janeiro. 160p.

Till, W. 1994. The type specimens of Bromeliaceae in the herbarium of the Museum of Natural History in Vienna, Austria. Selbyana 15: 94-111.
Wawra, H. 1883-1888. Itinera Principum S. Coburgi. Die botanische Ausbeute von den Reisen ihrer Hoheiten der Prinzen von Sachsen-Coburg-Gotha. I. Reise der Prizen Philipp und August um die Welt 918721873). II. Reise der Prizen August und Ferdinand nach Brasilien beschreiben von Dr. Heinrich Ritter Wawra v Fernsee. Druck und Commissionsverlag von Carl Gerold's sohn, Wien. 221 p.

Wendt, T. 1997. A review of the subgenus Pothuava (Baker) Baker of Aechmea Ruiz \& Pav. (Bromeliaceae) in Brazil. Botanical Journal of the Linnean Society 125: 245-271. 